\title{
For the want of an heir: the obstetrical history of Queen Anne
}

\author{
H E Emson
}

Queen Anne had 17 recorded pregnancies but failed to leave an heir to the throne, and the succession passed to the Elector of Hanover, who became George I of England. Anne's disastrous obstetrical history was dynastically important and this has added interest to the purely medical aspects. Ever since her death there has been speculation on her recurrent fetal loss, and recent discoveries now enable us to give a coherent scientific explanation, linking this loss with her other illnesses.

Anne's early medical history was marked by only a "defluxion" of the eyes, a constant watering for which she visited a French oculist at the age of 4 . This persisted all her life and gave her problems with reading, especially by candlelight. Stenosis of the nasolacrimal ducts seems a likely diagnosis. She had smallpox, fortunately a mild attack, and was troubled by blushing all her life, which may be more important.

In 1683, aged 17, she married Prince George of Denmark, an arranged union with a Protestant prince which turned out happily for them both. George was a man of monumental dullness, distinguished only by his appetites for food and drink, his mild military ambitions, which were squashed by William of Orange when he became king, and his asthma. One wag said that his heavy breathing was all that convinced people he was in fact alive.

Anne's prompt first pregnancy ended with a stillborn daughter. Two daughters were born in 1685 and 1686 but died of smallpox in 1687 . Three miscarriages followed, and in 1689 William Duke of Gloucester was born. He was always a weakly child, with a head too big for his body; he had difficulty in walking, running, and getting to his feet if he fell. He seems to have had some form of hydrocephalus, and the painting by Closterman in the National Portrait Gallery in London certainly suggests this, though presumably in suitably modified form. He was of normal intelligence, but died from a fever a few days after his 11th birthday in 1700 .

After Gloucester's birth there followed a daughter and a son who each lived less than a day. Anne then had a sequence of eight pregnancies, none of which resulted in a living child. The last of these was in 1700 . One is recorded as a double gestation, a boy of 7 months' growth and another of 2 or 3 months, presumably a blighted twin. Anne succeeded to the throne on the death of William of Orange in 1702. George of Denmark died in 1708 and Anne in 1714 at the age of 49 .

The first stillbirth may or may not be important. The deaths of Anne's daughters from smallpox and her son's hydrocephalus and death from fever are unrelated to her own medical history. It is the 11 miscarriages and the two neonatal deaths that we must consider, and we must take into account the fact that her last 10 pregnancies did not produce a child who lived more than two hours.

Royal University Hospital, Saskatoon, Canada S7N 0X0

H E Emson, professor of pathology

BMF 1992;304:1365-6

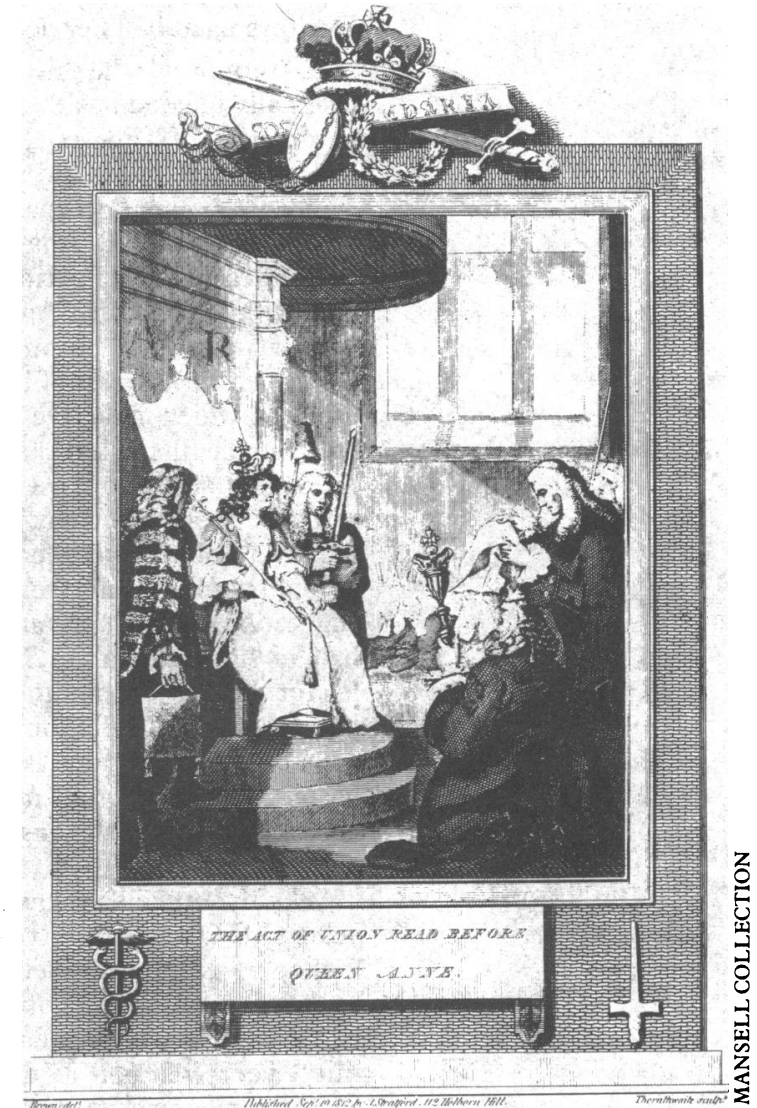

None of the last eight of Queen Anne's 17 pregnancies resulted in a living child. Her only surviving child died in 1700, at the age of 11; in 1702 Anne succeeded to the throne and thereafter was heavily occupied by affairs of state

the diarist Luttrell when Anne was 33, and frequently referred to for the rest of her life. Gout is rare in women, very rare before the menopause, and characteristically recurs in a single joint. Anne's "gout" affected her feet, knees, hands, and other joints; it was a migratory polyarthritis, which was painful. There is a record by Swift of her having "gout in her bowels," but he was a notoriously unreliable witness, and the diagnosis may mean anything or nothing in modern terms. How much of Anne's disability was due to polyarthritis and how much to her considerable obesity, which likely gave rise to degenerative arthritis, we cannot determine, but aged 35 she was carried to her coronation in a sedan chair, and she had difficulty in walking for the rest of her life. It was said that she had the contrivances built to raise Henry VIII between the floors of Hampton Court repaired for her own use.

Anne suffered from a facial skin eruption, which initially coincided with attacks of "gout." In $1706 \mathrm{Sir}$ John Clerk recorded, "Her Majesty was labouring under a fit of the gout and in extreme pain and agony ... her face was red and spotted." In 1708 the same diarist said, "The poor lady was again under a severe fit of the gout . . . blotted in her countenance." In 1713 Coke wrote, "She did not look like the same person as before, and therefore 'twas expedient to use
There are three other important entries in Anne's medical record, together with some which are either of minor relevance or which cannot be evaluated properly. The most important is "gout," first recorded in 1698 by 
paint to disguise the discolourings; but this was kept so secret that it was never so much as whispered abroad in her lifetime."

Finally, from time to time Anne was said to have the dropsy-abnormal accumulation of fluid, either oedema or in the serous cavities. This allegation was hotly denied by her physician, Sir David Hamilton, at the time of her death and autopsy; he seems to have been very irritated by it, possibly because it reflected on his medical management.

\section{Doctors hastened her death}

In summary, the history is of a young woman, originally in good health, who had, in all, 17 recorded pregnancies. Of these, the last 10 were unsuccessful pregnancies between the ages of 25 and 35, after which she never became pregnant again. Eleven of the total are recorded as stillbirths, though for only one is there any indication of the period of gestation. Two children died within two hours. Aged 33 she had her first attack of what proved to be migratory polyarthritis, which continued for the rest of her life. She had a facial skin eruption which may have been intermittent at first and associated with her attacks of arthritis but then became fixed, and she may have had peripheral oedema and serous effusions. After the age of 30 she became massively obese and she died at the age of 49 . The accounts of her death are typically obscure. There is a suggestion of a petit mal attack and of convulsions. She had an "impostumation," probably an abscess, on her leg for the last few months of her life, and septicaemia is a possibility. Hamilton's final account of "the gout ascending to her brain" is not helpful. ${ }^{2}$ Her death was hastened by her doctors' ministrations, which included cupping, emetics, shaving her head, and laying garlic at her feet.

Why did Anne's pregnancies cease after she was 33 years old? One possibility is that the cause of her fetal loss operated progressively earlier in each pregnancy, so that later ones were not recognised as such. Another is the onset of pelvic inflammatory disease and infertility, very common at that time. She did not have an early menopause; her physician's reference, "the Menses happend to her as if she had been but 20 years old," is in 1710 when she was $45 .^{2}$ She and her husband may have diminished the frequency of intercourse or ceased altogether: Anne was obese and in constant pain from arthritis and George was obese and asthmatic. After her accession in 1702 she was heavily occupied with affairs of state.

There have been various suggestions about her underlying disease. The old canard of syphilis has been trotted out, as it has for the illness of every royal person since Henry VIII and with as little truth. Syphilis does not behave in this way, and there was no suggestion of the disease in Anne or her husband. Porphyria afflicted the royal line from James I of England and later caused the intermittent insanity of George III, but despite its protean manifestations it does not fit with Anne's condition. ${ }^{3}$ Infection with Listeria monocytogenes has been postulated as the cause of her miscarriages, but does nothing to explain her other illnesses. ${ }^{4}$ Rhesus autoimmunisation should have given one or two successful initial pregnancies, followed by earlier and earlier abortions, but again it does not correlate with her other symptoms.

\section{Most likely single cause}

The most likely single diagnosis that does account for Anne's multiple problems is disseminated lupus erythematosus: sex, age, polyarthritis, and facial eruption are all typical. Renal involvement cannot be proved, but if she did indeed have dropsy it might have been caused by renal failure, and hypertension of renal origin might have been a factor in her death. The discovery of lupus anticoagulant and its association with repeated abortion in young women is the final link. The antibody was first described in 1975 as an antithromboplastin, ${ }^{5}$ and its association with lupus was established shortly thereafter. ${ }^{6}$ It has been found to interfere with prostacyclin formation, ${ }^{7}$ and patients have been treated successfully with steroids. ${ }^{8}$

Sequential loss of pregnancies may precede the other symptoms of lupus. In one published series two thirds of fetal losses occurred in the first trimester. ${ }^{8}$ Recent articles have reviewed the relation between lupus antibodies and fetal loss. ${ }^{910}$ Knowledge of this antibody and its effects completes a diagnosis based on Anne's various symptoms and permits explanation of her medical history as an entity. Indeed, thromboembolic disease associated with lupus anticoagulant may have been a factor in Anne's death, but we cannot be certain.

Other forms of seronegative arthritis also produce severe pain and incapacity and more often than lupus. We do not know how much of Anne's disability was due to polyarthritis and how much to her massive obesity. There is no record of her having continued bowel disease. Episodes of presumed gastroenteritis are recorded, but no more often than was customary for the period in a person of noted gastronomic excess, and seronegative arthritis has never been linked with successive loss of pregnancies.

\section{A great monarch despite everything}

Taking all these factors into account, disseminated lupus erythematosus seems the most likely diagnosis, and no other syndrome has been suggested which takes into account all of her symptoms. It is always satisfying to achieve a single diagnosis that explains multiple organ and system involvement and clarifies an obscure and complex clinical course.

Poor Anne. Despite all her suffering she managed to be a great English monarch. Her support of Marlborough decisively broke the power of France and changed Europe's history. Parliamentary government evolved during her reign. There remains one of history's great might have beens. Suppose Anne had produced a living heir, originated a line of Protestant Stuarts, and that the Hanoverian Georges had never become English. It would have been a very different world.

1 Green D. Queen Anne. New York: Charles Scribner's Sons, 1970.

2 Roberts P, ed. The diary of Sir David Hamilton 1709-1714. Oxford: Clarendon Press, 1975

3 McAlpine I, Hunter R. The insanity of George III: a classic case of porphyria. BMF 1966;i:65-71.

4 Saxbe WE. Listeria monocytogenes and Queen Anne. Pediatrics 1972;49: 97-101.

5 Nilsson IM, Astedt B, Hedner U, Berezin D. Intrauterine death and circulating anticoagulant, "antithromboplastin." Acta Med Scand 1975;197; 153-9.

6 Firkin BG, Howard MA, Radford N. Possible relationship between lupus inhibitor and recurrent abortion in young women. Lancet 1980;ii:366.

7 Carreras LO, Vermylen J, Spitz B, Van Assche A. Lupus anticoagulant and inhibition of prostacyclin formation in patients with repeated abortion, intrauterine growth retardation and intrauterine death. Brf Obstet Gynaecol 1981;88:890-4.

8 Lubbe WF, Butler WS, Liggins GC. The lupus anti-coagulant: clinical and obstetric implications. N Z Med I 1984;97:398-402.

9 Love PE, Santoro SA. Antiphospholipid antibodies; cardiolipin and the lupus anticoagulant in systemic lupus erythematosus (SLE) and in non-SLE disorders. Ann Intern Med 1990;112:682-98.

10. Qmar T, Levy RA, Sammaritano L, Gharavi AE, Lockshin MD. Characteristics of high-titre IgG antiphospholipid antibody in systemic lupus erythematosus patients with and without fetal death. Arthritis Rheum 1990;33:501-4. 